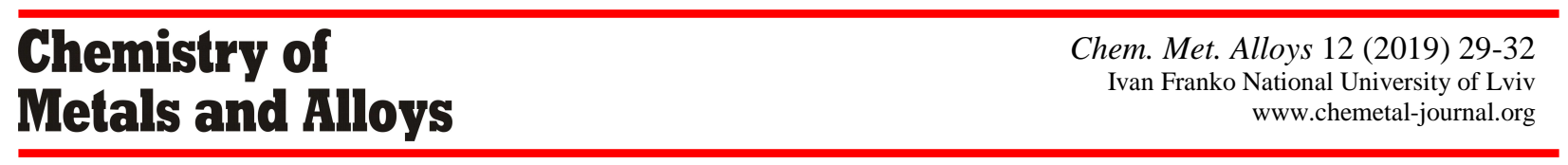

\title{
Crystal structure of a solid solution in the Mg-Pd-Al system
}

\author{
Vasyl STOTSKYI ${ }^{1 *}$, Svitlana PUKAS ${ }^{1}$, Roman GLADYSHEVSKII $^{1}$ \\ ${ }^{1}$ Department of Inorganic Chemistry, Ivan Franko National University of Lviv, \\ Kyryla i Mefodiya St. 6, 79005 Lviv, Ukraine \\ * Corresponding author.Tel.: +380-32-2394506; e-mail: vasylchemscientist@gmail.com
}

Received May 12, 2019; accepted June 18, 2019; available on-line January 1, 2020

https://doi.org/10.30970/cma12.0391

A search for new ternary palladium aluminides was carried out in the system Mg-Pd-Al. A new phase was observed in two alloys of nominal compositions $\mathbf{M g}_{7.1} \mathbf{P d}_{28.6} \mathbf{A l}_{64.3}$ and $\mathbf{M g}_{11.1} \mathbf{P d}_{33.3} \mathbf{A l}_{55.6}$; phase and structural analyses were performed based on $\mathrm{X}$-ray powder diffraction data. A crystal structure corresponding to partial substitution of $\mathrm{Mg}$ in the binary compound $\mathrm{Pd}_{8} \mathrm{Al}_{21}\left(\mathbf{P t}_{8} \mathrm{Al}_{21}\right.$-type, Pearson symbol $t$ I116, space group $\left.I_{1} / a\right)$ was established. The approximate composition $\mathrm{Mg}_{5} \mathrm{Pd}_{8} \mathrm{Al}_{16}$ was determined by energy-dispersive $\mathrm{X}$-ray spectroscopy for the phase in the Mg-poor sample $(a=13.0429(2), c=10.6880(1) \AA)$ and it was assumed, based on geometrical arguments, that $\mathrm{Mg}$ atoms replace $\mathrm{Al}$ atoms in Wyckoff position $4 a$ and one of the seven positions 16f. The phase in the Mg-rich sample $(a=13.1928(4), c=10.6488(5) \AA)$ was found to contain more $\mathrm{Mg}$, indicating the existence of a solid solution. Compared to the binary compound $\mathbf{P d}_{8} \mathrm{Al}_{21}$, the $a$-parameter is also larger but the $c$-parameter shorter, leading to an overall increase of the cell volume with increasing Mg content.

Ternary palladium aluminide / X-ray powder diffraction / Energy-dispersive X-ray spectroscopy / Crystal structure

\section{Introduction}

Seven ternary compounds have been reported in the $\{\mathrm{Mg}, \mathrm{Ca}, \mathrm{Sr}, \mathrm{Ba}\}-\mathrm{Pd}-\mathrm{Al}$ systems $[1,2]$. The crystal structures of these aluminides belong to seven different structure types, among which five are defined on ternary compounds with alkaline-earth metals and three of them are own types (Table 1). Four structure types, $\mathrm{Ca}_{2} \mathrm{Ir}_{2} \mathrm{Si}$, CaPdAl, $\mathrm{Ca}_{2} \mathrm{Pd}_{2} \mathrm{Ge}$, and $\mathrm{Sr}_{2} \mathrm{Pd}_{4} \mathrm{Al}_{5}$, are characterized by well-defined compositions and complete ordering of the atoms in the structures, whereas the compounds crystallizing with the other three structure types, $\mathrm{Li}_{13}\left(\mathrm{Cu}_{0.53} \mathrm{Si}_{0.47}\right)_{27}$, $\mathrm{Ca}_{2} \mathrm{Pd}_{6} \mathrm{Al}_{10}$, and $\mathrm{LaFe}_{9} \mathrm{Al}_{4}$, exhibit partial $\mathrm{Pd} / \mathrm{Al}$ atom disorder. The aim of the present work was to search for new ternary palladium aluminides with alkalineearth metals, in particular with magnesium.

\section{Experimental}

Samples of nominal compositions $\mathrm{Mg}_{7.1} \mathrm{Pd}_{28.6} \mathrm{Al}_{64.3}$ and $\mathrm{Mg}_{11.1} \mathrm{Pd}_{33.3} \mathrm{Al}_{55.6}$ were synthesized from the elements (purity for $\mathrm{Mg} \geq 99.4, \quad \mathrm{Pd} \geq 99.99$, $\mathrm{Al} \geq 99.998$ mass \%) by arc melting in a water-cooled copper crucible with a tungsten electrode under a purified argon atmosphere (using $\mathrm{Ti}$ as a getter). The ingots were annealed at $400^{\circ} \mathrm{C}$ under vacuum in quartz ampoules for $1000 \mathrm{~h}$ and subsequently quenched in cold water.

The crystal structures of the phases were established by X-ray powder diffraction. The data were collected at room temperature on an automatic diffractometer STOE Stadi $\mathrm{P}\left(\mathrm{Cu} K \alpha_{1}\right.$ radiation, $\lambda=1.5406 \AA$, in the angular range $5 \leq 2 \theta \leq 110.615^{\circ}$ with step $0.015^{\circ}$ and scan time $320 \mathrm{~s}$ ). The structural parameters were refined by the Rietveld method [10], using the program DBWS [11]. The elemental compositions of the phases in the sample with lower $\mathrm{Mg}$ content were determined by energy-dispersive X-ray spectroscopy on a scanning electron microscope REMMA-102-02. The structure drawings were made with the program ATOMS [12].

\section{Results and discussion}

The phase analysis of the alloys showed that the samples contained a phase with a structure related to the tetragonal $\mathrm{Pt}_{8} \mathrm{Al}_{21}$-type and the known binary compound $\mathrm{Pd}_{2} \mathrm{Al}_{3}$. The compositions of both phases were determined by EDX analysis (Fig. 1). Based on the X-ray diffraction data, the structural parameters of the new phase were refined. 
Table 1 Crystallographic parameters of compounds reported in the $\{\mathrm{Mg}, \mathrm{Ca}, \mathrm{Sr}, \mathrm{Ba}\}-\mathrm{Pd}-\mathrm{Al}$ systems.

\begin{tabular}{c|c|c|c|c|c|c|c}
\hline Compound & $\begin{array}{c}\text { Structure } \\
\text { type }\end{array}$ & $\begin{array}{c}\text { Pearson } \\
\text { symbol }\end{array}$ & $\begin{array}{c}\text { Space } \\
\text { group }\end{array}$ & $a, \AA$ & $b, \AA$ & $c, \AA$ & Ref. \\
\hline $\mathrm{Mg}_{16} \mathrm{Pd}_{4.4} \mathrm{Al}_{19.6}$ & $\mathrm{Li}_{13}\left(\mathrm{Cu}_{0.53} \mathrm{Si}_{0.47}\right)_{27}$ & $c I 160$ & $I m-3$ & 14.245 & - & - & {$[3]$} \\
$\mathrm{Ca}_{2} \mathrm{Pd}_{2} \mathrm{Al}$ & $\mathrm{Ca}_{2} \mathrm{Ir}_{2} \mathrm{Si}$ & $m S 20$ & $C 2 / c$ & 10.017 & 5.7669 & 7.7421 & {$[4]$} \\
$\mathrm{CaPdAl}$ & $\mathrm{CaPdAl}_{2} \mathrm{P}$ & $o P 12$ & $P b c m$ & 5.75 & 7.79 & 5.62 & {$[5]$} \\
$\mathrm{Ca}_{2} \mathrm{Pd}_{6} \mathrm{Al} l_{10}$ & $\mathrm{Ca}_{2} \mathrm{Pd}_{6} \mathrm{Al}_{10}$ & $h P 18$ & $P 6 / m m m$ & 9.373 & - & 4.248 & {$[6]$} \\
$\mathrm{Sr}_{2} \mathrm{Pd}_{2} \mathrm{Al}$ & $\mathrm{Ca}_{2} \mathrm{Pd}_{2} \mathrm{Ge}$ & $o F 40$ & $F d d 2$ & 10.4145 & 15.5824 & 6.0437 & {$[7]$} \\
$\mathrm{Sr}_{2} \mathrm{Pd}_{4} \mathrm{Al}_{5}$ & $\mathrm{Sr}_{2} \mathrm{Pd}_{4} \mathrm{Al}_{5}$ & $o P 44$ & $P n m a$ & 18.1449 & 4.3164 & 11.0247 & {$[8]$} \\
$\mathrm{BaPd}_{4.5} \mathrm{Al}_{8.5}$ & $\mathrm{LaFe}_{9} \mathrm{Si}_{4}$ & $t I 56$ & $I 4 / m c m$ & 8.7259 & - & 12.4571 & {$[9]$} \\
\hline
\end{tabular}

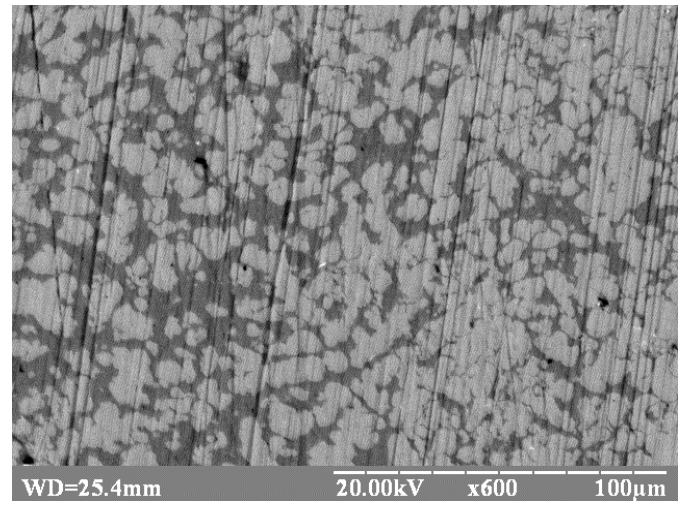

Fig. 1 Electron microscope photograph of the alloy $\mathrm{Mg}_{7.1} \mathrm{Pd}_{28.6} \mathrm{Al}_{64.3}: \mathrm{Mg}_{16.7} \mathrm{Pd}_{27.3} \mathrm{Al}_{56.0}$ $\left(\mathrm{Mg}_{5} \mathrm{Pd}_{8} \mathrm{Al}_{16}\right)$ - dark gray, $\mathrm{Pd}_{39.7} \mathrm{Al}_{60.3}$ $\left(\mathrm{Pd}_{2} \mathrm{Al}_{3}\right)$ - light gray).

In the case of the alloy $\mathrm{Mg}_{7.1} \mathrm{Pd}_{28.6} \mathrm{Al}_{64.3}$, the composition of the new phase, for which an ordered arrangement of atoms in the structure is proposed, can be described by the approximate formula $\mathrm{Mg}_{5} \mathrm{Pd}_{8} \mathrm{Al}_{16}$, and in the case of the alloy $\mathrm{Mg}_{11.1} \mathrm{Pd}_{33.3} \mathrm{Al}_{55.6}$, by the formula $\mathrm{Mg}_{5+x} \mathrm{Pd}_{8} \mathrm{Al}_{16-x}$. The crystal structure of the ternary phase is a derivative of the $\mathrm{Pt}_{8} \mathrm{Al}_{21}$-type structure [13], with the same space group $I 4_{1} / a$ and 116 atoms per unit cell. Comparing the unit-cell parameters of the binary compound $\mathrm{Pd}_{8} \mathrm{Al}_{21}$ $\left(a=12.998, c=10.729 \AA, V=1812.6 \AA^{3}\right.$ [14]) with those of the ternary phase synthesized here $\left(a=13.0429(2), c=10.6880(1) \AA, V=1818.19(4) \AA^{3}\right.$ for the composition $\mathrm{Mg}_{5} \mathrm{Pd}_{8} \mathrm{Al}_{16}$ and $a=13.1928(4)$, $c=10.6488(5) \AA, \quad V=1853.42(12) \AA^{3}$ for the composition $\mathrm{Mg}_{5+x} \mathrm{Pd}_{8} \mathrm{Al}_{16-x}$ ), we observe an increase of the $a$-parameter and a decrease of the $c$-parameter for the Mg-containing phase.

Experimental details and crystallographic data for the Rietveld refinement of the sample $\mathrm{Mg}_{7.1} \mathrm{Pd}_{28.6} \mathrm{Al}_{64.3}$ are presented in Table 2. Atomic coordinates and isotropic displacement parameters for $\mathrm{Mg}_{5} \mathrm{Pd}_{8} \mathrm{Al}_{16}$ are given in Table 3 . A comparison of the experimental and calculated diffraction diagrams for the sample $\mathrm{Mg}_{7.1} \mathrm{Pd}_{28.6} \mathrm{Al}_{64.3}$ is shown in Fig. 2 .

Due to the similar atomic form factors of $\mathrm{Mg}$ and $\mathrm{Al}$ (12 and 13 electrons, respectively) the distribution of $\mathrm{Mg}$ and $\mathrm{Al}$ atoms on the different atom sites was made based on crystal chemical considerations. Hence, the larger, $\mathrm{Mg}$ atoms (atomic radii $r_{\mathrm{Mg}}=1.60$, $\left.r_{\mathrm{Al}}=1.43 \AA[15]\right)$, were assumed to occupy the site in Wyckoff position $4 a$, for which the longest contact interatomic distances (2.674-2.863 $\AA$ ) were observed, and one of the seven sites in Wyckoff position $16 f$, for which the highest coordination number was observed (15). For the $\mathrm{Al}$ atoms, the values of the shortest distances within the coordination polyhedra are: $\mathrm{Al} 1$ - 2.578, Al2 - 2.573, Al3 - 2.576, Al4 - 2.562 A.

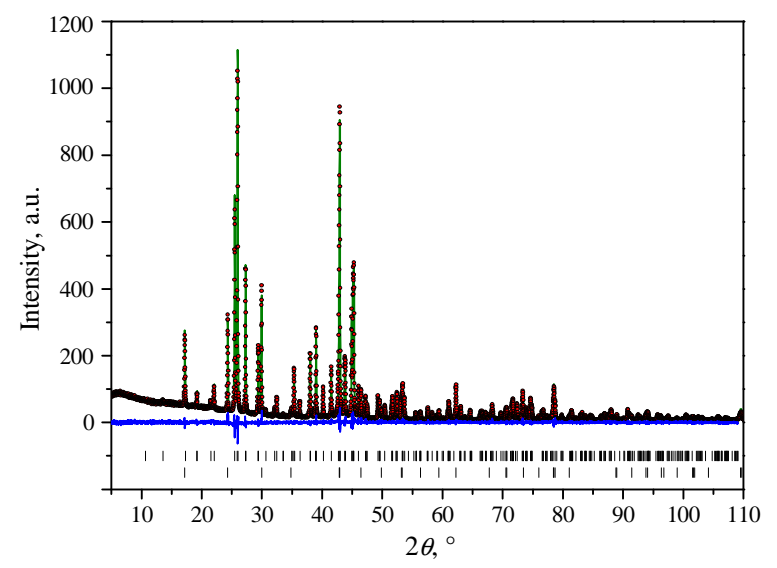

Fig. 2 Experimental, calculated and difference between experimental and calculated X-ray powder diffraction patterns $\left(\mathrm{Cu} K \alpha_{1}\right.$ radiation) for the sample $\mathrm{Mg}_{7.1} \mathrm{Pd}_{28.6} \mathrm{Al}_{64.3}$. Vertical bars indicate the positions of the reflections of $\mathrm{Mg}_{5} \mathrm{Pd}_{8} \mathrm{Al}_{16}$ and $\mathrm{Pd}_{2} \mathrm{Al}_{3}$.

A projection of the unit cell of the structure of the new compound along the crystallographic direction [001], and the different coordination polyhedra, are presented in Fig. 3. The coordination polyhedra of the $\mathrm{Mg}$ atoms are icosahedra of composition $\mathrm{Mg}_{4} \mathrm{Pd}_{4} \mathrm{Al}_{4}$ (site $\mathrm{Mg} 1$, Wyckoff position $4 a$ ) and 15-vertex Frank-Kasper polyhedra of composition $\mathrm{Mg}_{2} \mathrm{Pd}_{4} \mathrm{Al}_{9}(\mathrm{Mg} 2,16 f)$. The $\mathrm{Pd}$ atoms are situated inside defective icosahedra of compositions $\mathrm{Mg}_{3} \mathrm{Al}_{7}$ (site $\mathrm{Pd} 1$ ) and $\mathrm{Mg}_{2} \mathrm{Al}_{8}$ (Pd2). 
Table 2 Details of the Rietveld refinement of the sample $\mathrm{Mg}_{7.1} \mathrm{Pd}_{28.6} \mathrm{Al}_{64.3}$.

\section{Compound}

Content, mass \%

Structure type

Space group

Cell parameters $a, c, \AA$

Cell volume $V, \AA^{3}$

Formula units per cell $Z$

Density $D_{\mathrm{X}}, \mathrm{g} \mathrm{cm}^{-3}$

Texture parameter $G$ [direction]

Number of reflections

Reliability factor $R_{\mathrm{B}}$

FWHM parameters $U, V, W$

Mixing parameter $\eta$

Asymmetry parameter $C_{\mathrm{M}}$

Number of refined parameters

Reliability factors $R_{\mathrm{p}}, R_{\mathrm{wp}}$

Goodness of fit $S$

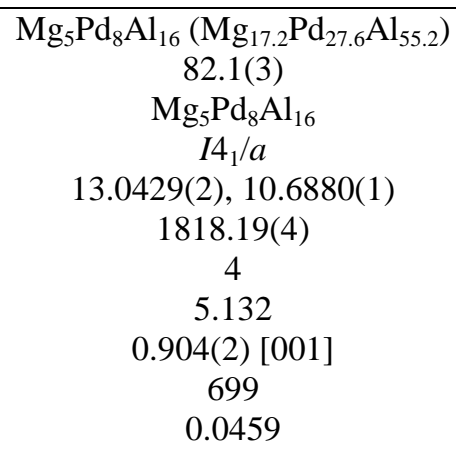

5.132

$0.904(2)$ [001]

699

0.0459

0.0339(6), 0.0094(3), 0.0089(1)

$0.591(5)$

$-0.078(5)$

38

$0.0587,0.0807$

$0.97(1)$

Table 3 Atom coordinates and isotropic displacement parameters for $\mathrm{Mg}_{5} \mathrm{Pd}_{8} \mathrm{Al}_{16}: t I 116, I 4{ }_{1} / a$, $a=13.0429(2), c=10.6880(1) \AA$.

\begin{tabular}{|c|c|c|c|c|c|}
\hline Site & Wyckoff position & $x$ & $y$ & $z$ & $B_{\text {iso }}, \AA^{2}$ \\
\hline $\begin{array}{l}\mathrm{Mg} 1 \\
\mathrm{Mg} 2\end{array}$ & $\begin{array}{l}4 a \\
16 f\end{array}$ & $\begin{array}{c}0 \\
0.4246(5)\end{array}$ & $\begin{array}{c}1 / 4 \\
0.1570(6)\end{array}$ & $\begin{array}{c}1 / 8 \\
0.1531(6)\end{array}$ & $0.87(9)$ \\
\hline $\begin{array}{l}\mathrm{Pd} 1 \\
\mathrm{Pd} 2\end{array}$ & $\begin{array}{l}16 f \\
16 f\end{array}$ & $\begin{array}{l}0.1296(1) \\
0.0989(2)\end{array}$ & $\begin{array}{l}0.1546(2) \\
0.5380(1)\end{array}$ & $\begin{array}{l}0.2800(1) \\
0.3287(1)\end{array}$ & $0.42(2)$ \\
\hline $\begin{array}{l}\text { Al1 } \\
\text { Al2 } \\
\mathrm{Al} 3 \\
\mathrm{Al} 4\end{array}$ & $\begin{array}{l}16 f \\
16 f \\
16 f \\
16 f\end{array}$ & $\begin{array}{c}0.0906(6) \\
0.0877(6) \\
0.2171(7) \\
0.0085(5)\end{array}$ & $\begin{array}{l}0.1937(5) \\
0.0020(5) \\
0.0376(6) \\
0.0311(6)\end{array}$ & $\begin{array}{c}0.5231(5) \\
0.4266(5) \\
0.0986(6) \\
0.1418(6)\end{array}$ & $1.02(6)$ \\
\hline
\end{tabular}

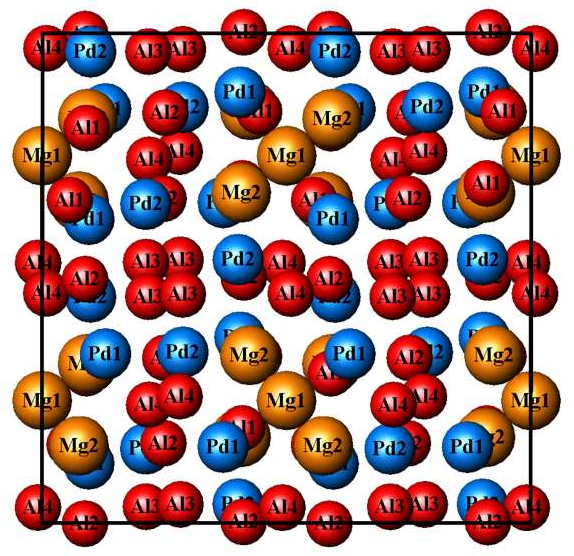

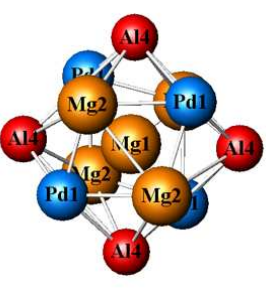

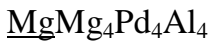

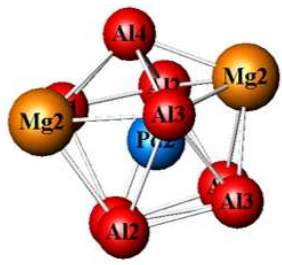

$\underline{\mathrm{Pd}} \mathrm{Mg}_{2} \mathrm{Al}_{8}$

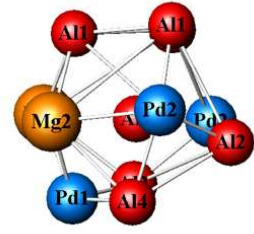

$\underline{\mathrm{AlMg}_{2}} \mathrm{Pd}_{3} \mathrm{Al}_{6}$

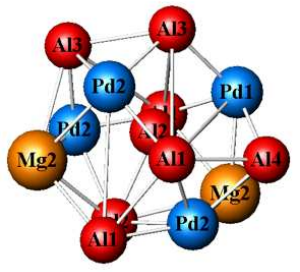

$\underline{\mathrm{AlMg}} \mathrm{Pd}_{4} \mathrm{Al}_{7}$

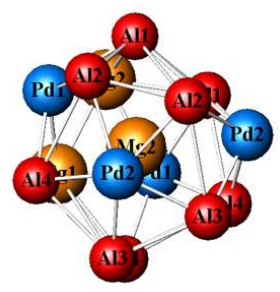

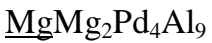

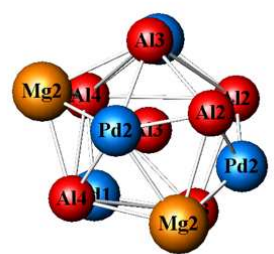

$\underline{\mathrm{AlMg}} \mathrm{Pd}_{4} \mathrm{Al}_{6}$

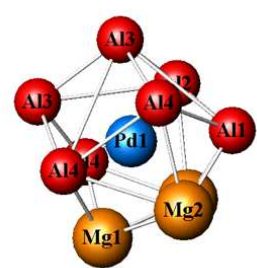

$\underline{\mathrm{Pd}} \mathrm{Mg}_{3} \mathrm{Al}_{7}$

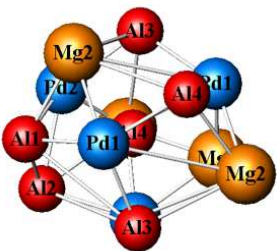

$\underline{\mathrm{AlMg}} \mathrm{Pd}_{4} \mathrm{Al}_{5}$

Fig. 3 Projection of the structure of $\mathrm{Mg}_{5} \mathrm{Pd}_{8} \mathrm{Al}_{16}$ along [001] and coordination polyhedra. 
The $\mathrm{Al}$ atoms from the site $\mathrm{Al} 3$ are located inside icosahedra of composition $\mathrm{Mg}_{2} \mathrm{Pd}_{4} \mathrm{Al}_{6}$, whereas the $\mathrm{Al}$ atoms from the site $\mathrm{All}$ center defective icosahedra of the composition $\mathrm{Mg}_{2} \mathrm{Pd}_{3} \mathrm{Al}_{6}$. The polyhedra surrounding the $\mathrm{Al}$ atoms from the two other sites, $\mathrm{Al} 2$ and $\mathrm{Al} 4$, have 13 vertices and can be considered as pseudo Frank-Kasper coordination polyhedra of compositions $\mathrm{Mg}_{2} \mathrm{Pd}_{4} \mathrm{Al}_{7}$ and $\mathrm{Mg}_{4} \mathrm{Pd}_{4} \mathrm{Al}_{5}$, respectively.

The structure of the compound $\mathrm{Mg}_{5} \mathrm{Pd}_{8} \mathrm{Al}_{16}$ is an ordered ternary derivative of the binary structure type $\mathrm{Pt}_{8} \mathrm{Al}_{21}$. Another ordered ternary derivative of the $\mathrm{Pt}_{8} \mathrm{Al}_{21}$-type is the $\mathrm{Pd}_{8} \mathrm{Al}_{17} \mathrm{Si}_{4}$ structure [16], where the $\mathrm{Si}$ atoms occupy the position of Al1, which is characterized by the smallest coordination number.

As mentioned above, the only compound reported previously in the $\mathrm{Mg}-\mathrm{Pd}-\mathrm{Al}$ system, $\mathrm{Mg}_{16} \mathrm{Pd}_{4.4} \mathrm{Al}_{19.6}$, crystallizes with a structure for which partial disorder $\mathrm{Pd} / \mathrm{Al}$ was found, whereas the other sites were occupied exclusively by $\mathrm{Mg}$ atoms [3]. In the solid solution studied here, the $\mathrm{Pd}$ atoms were found to occupy two of the atom sites at all compositions, whereas preferential substitution of $\mathrm{Mg}$ for $\mathrm{Al}$ on certain atom sites is proposed for $\mathrm{Mg}_{5} \mathrm{Pd}_{8} \mathrm{Al}_{16}$. Partial $\mathrm{Mg} / \mathrm{Al}$ disorder is expected to occur within the homogeneity range of the solid solution. Both statistical mixtures $\mathrm{Pd} / \mathrm{Al}$ and $\mathrm{Mg} / \mathrm{Al}$ are well known in the literature [1].

\section{Conclusions}

A ternary phase of approximate composition $\mathrm{Mg}_{5+x} \mathrm{Pd}_{8} \mathrm{Al}_{16-\mathrm{x}}$, crystallizing with the structure type $\mathrm{Pt}_{8} \mathrm{Al}_{21}$, was identified in the ternary system $\mathrm{Mg}-\mathrm{Pd}-\mathrm{Al}$ at $400^{\circ} \mathrm{C}$. The substitution of $\mathrm{Al}$ atoms by slightly larger $\mathrm{Mg}$ atoms is accompanied by an increase of the volume of the unit cell, however, the cell parameters change anisotropically ( $a$ increases, $c$ decreases). For the composition $\mathrm{Mg}_{5} \mathrm{Pd}_{8} \mathrm{Al}_{16}$, an ordered structure model is propose, in which the $\mathrm{Mg}$ atoms occupy the sites with the longest contact distances and the largest coordination number. Further investigation of the phase diagram of the $\mathrm{Mg}-\mathrm{Pd}-\mathrm{Al}$ system is needed to establish the extension of the solid solution and the existence, or absence, of a two-phase region between $\mathrm{Pd}_{8} \mathrm{Al}_{21}$ and $\mathrm{Mg}_{5} \mathrm{Pd}_{8} \mathrm{Al}_{16}$.

\section{Acknowledgements}

This work was supported by the Ministry of Education and Science of Ukraine (grant No. 0118U003609).

\section{References}

[1] P. Villars, K. Cenzual (Eds.), Pearson's Crystal Data - Crystal Structure Database for Inorganic Compounds, ASM International, Materials Park, OH, USA, Release 2017/18.
[2] P. Villars, K. Cenzual, R. Gladyshevskii (Eds.), Handbook of Inorganic Substances 2017, De Gruyter, Berlin, Germany, 2017, 1955 p. https://doi.org/10.1515/9783110445404

[3] T. Takeuchi, U. Mizutani, S. Yamaguchi, T. Fukunaga, T. Mizuno, N. Tanaka, Phys. Rev. B. 58 (1998) 11345-11353.

https://doi.org/10.1103/PhysRevB.58.11345

[4] I. Doverbratt, S. Ponou, Y. Zhang, S. Lidin, G.J. Miller, Chem. Mater. 27 (2015) 304-315. https://doi.org/10.1021/cm503985h

[5] G. Cordier, T. Friedrich, Kristallogr. 205 (1993) 135-136. https://doi.org/10.1524/zkri.1993.205.Part-1.135

[6] G. Cordier, G. Dörsam, T. Friedrich, R. Henseleit, C. Röhr, J. Alloys Compd. 190 (1993) 201-207. https://doi.org/10.1016/0925-8388(93)90400-H

[7] F. Stegemann, C. Benndorf, R.S. Touzani, B.P.T. Fokwa, O. Janka, J. Solid State Chem. 242 (2016) 143-150. https://doi.org/10.1016/j.jssc.2016.07.019

[8] F. Stegemann, C. Benndorf, R.S. Touzani, B.P.T. Fokwa, O. Janka, Eur. J. Inorg. Chem. (2016) 1108-1114. https://doi.org/10.1002/ejic.201501455

[9] V. Stotskyy, S. Pukas, L. Akselrud, R. Gladyshevskii, Coll. Abstr. XIII Int. Conf. Crystal Chem. Intermet. Compd., Lviv, 2016, p. 96.

[10] R.A. Young (Ed.), The Rietveld Method, Oxford University Press, Oxford, United Kingdom, 1995, 298 p.

[11] R.A. Young, A. Sakthivel, T.S. Moss, C.O. Paiva-Santos, J. Appl. Crystallogr. 28 (1995) 366-367. https://doi.org/10.1107/S0021889895002160

[12] E. Dowty, ATOMS. A Computer Program for Displaying Atomic Structures, Kingsport, TN, USA, 1999.

[13] L.E. Edshammar, Acta Chem. Scand. 20 (1966) 2683-2688.

https://doi.org/10.3891/acta.chem.scand.20-2683

[14] M. Yurechko, A. Fattah, T. Velikanova, B. Grushko, J. Alloys Compd. 329 (2001) 173-181. https://doi.org/10.1016/S0925-8388(01)01605-X

[15] E. Teatum, K. Gschneidner, J. Waber, Report No. LA-2345, US Department of Commerce, Washington, D.C., USA, 1960.

[16] K.J. Range, E.G. Christl, J. Less-Common Met. 136 (1988) 277-285. https://doi.org/10.1016/0022-5088(88)90431-6 